\title{
Information histories, information geographies
}

Archie L Dick

University of Pretoria

Corresponding Author

Archie L Dick, Professor, Department of Information Science, University of Pretoria, Lynnwood Road, Pretoria, Republic of South Africa, 0002.

archie.dick@up.ac.za

\section{Abstract}

Information history, a promising new area of research, will benefit from a transnational perspective that makes it sensitive to the idea of place and that complicates issues of national information development and underdevelopment.

Keywords

Information history, information histories, information geographies, transnationalism, information development

Researching and teaching the role of information in national development should become more transnational in outlook. The journal's geographical coverage is impressive but few if any studies probe the roles that information played in the historical development of nationstates themselves, as well as of empires, and how networks of information disturb ideas of fixed geographical boundaries. These topics are not new in historical scholarship more generally (Bayly 1996; Said 1993). But information history, a youthful area of inquiry suggesting "a richness of unexplored avenues" (Weller 2011: 9), brings new possibilities.

Chief among them are a better understanding of the "shifting qualities of information itself", and a better understanding of the past and the present (Tredinnick 2011: 193). How we frame these understandings, however, is not without difficulties. This is apparent in Toni Weller's (2011) edited collection of essays on information history in the modern world, considered roughly as from the mid-eighteenth century onwards. Weller draws interesting 
conclusions from the interactions between oral and print cultures in France, England, and Denmark and the shift from pre-modern to modern understandings of information. She concludes that this shift marked the explicit recognition of information as a defining feature in the modern world, or of divorcing information from content, "as opposed to forming an implicit part of rhetorical discourse" (Weller 2011: 201).

Why is such a demarcation necessary? Based largely on the experiences of some European countries, are others around the world expected to pass through "pre-modern", "modern" and "post-modern" shifts in linear fashion? How are countries where oral and print cultures were disrupted or erased to be characterized? And, how does information geography feature in this information history? These questions take up Weller's commendable claim that "the plural is significant", and that there are "alternate histories" instead of "a single history of information" (Weller 2011: 2, 9). A transnational perspective makes information histories sensitive to information geographies, emphasizing the idea of place and complicating issues of information development and underdevelopment.

Enlarging the geographical focus brings on board themes of expansionism, trade, migration, information networks, and other topics that connect information histories with broader understandings of the past. Examples include: the data recording methods of the Roman army; methods of encrypting legal documents related to the Asian Silk Road in the third and fourth centuries; information and disinformation in the establishment of the Mongolian empire; early warning systems and the Hospitallers in the eastern Mediterranean; Dutch navigational knowledge of Japan in the early seventeenth century; and files on Prussian army conscripts in the early eighteenth century (Giannakopoulos 2011: 87-92). Continuities and changes in the methods of information collection, organization, dissemination, as well as the information systems and services that characterized information development in the nation-states shaped by these dramatic events will be instructive. 
The movements of goods and people, as well as their oral and print cultures that accompanied similar events can be understood along the historical and geographical lines drawn by powerful blocs, as for example a Cold War area studies map that still generally keeps apart scholarship from Africa, India, and Latin America. Alternative approaches, on the other hand, bring them together to introduce richer perspectives of information development (Delmas and Penn 2011; Gupta et al). These are the kinds of information histories and information geographies that are likely to bring symmetry to the history of European expansion, and a generally more balanced history. They will dispel the view in a UNESCO document on knowledge societies that still speaks of Africa as a "continent of oral tradition" (Towards knowledge societies 2005: 36). Diagne (2008:19) points out that this view that "African cultures are oral cultures in essence" fails to take account of the Timbuktu manuscripts and libraries, Islamic scholarship in Africa, the adoption of Arabic script, and Africa's written culture.

Timbuktu, in modern day Mali, was a centre of learning as far back as the eleventh century, with a high point in the sixteenth century. Going back even further is the Libyan script, an African native alphabet, which was used to write down ancient Libyan. Found on tombstones, it dates back more than two thousand years and is still used today by the Tuareg in its current form as the Tifinagh language (Le Quellec 2011: 8). Much remains to be done, but these are indications of some of the ways in which information was organized and distributed in Africa. Further work on such information histories and information geographies will enrich the contexts in which we understand how national information development unfolds. Teaching these research findings and debates is necessary.

\section{References}

Bayly, C (1996) Empire and information: Intelligence gathering and social communication in India, 1780-1870. Cambridge: Cambridge University Press.

Delmas, A and Penn, N (eds) (2011) Written cultures in a colonial context: Africa and the Americas, 1500-1900. Cape Town: UCT Press. 
Diagne, SB 2008 Toward an intellectual history of West Africa: the meaning of Timbuktu. In Jeppie, S and Diagne SB (eds). The meanings of Timbuktu. Pretoria: HSRC Press: 19-27.

Giannakopoulos, G, Sakas, DP, Vlachos, DS, and Kyriaki-Manessi, D (eds) (2011) International conference on integrated information: abstracts book. Piraeus: X. Mpenou.

Gupta, P, Hofmeyr, I, and Pearson M. (eds) 2010 Eyes across the water: Navigating the Indian ocean. Pretoria: Unisa Press.

Le Quellec, J 2011 Rock art, scripts and proto-scripts in Africa: The Libyco-Berber example. In: Delmas, A and Penn, N (eds) (2011) Written cultures in a colonial context: Africa and the Americas, 1500-1900. Cape Town: UCT Press: 3-29.

Said, E (1993) Culture and imperialism. London: Chatto and Windus.

Towards knowledge societies 2005 Unesco Publishing. Available at:

http://unesdoc.unesco.org/images/0014/001418/141843e.pdf (Accessed 25 February 2012)

Tredinnick, L (2011) Re-writing history: The information age and the knowable past. In Weller, T. (ed). Information history in the modern world: Histories of the information age. London: Palgrave Macmillan: 175-198.

Weller, T (ed) Information history in the modern world: Histories of the information age. London: Palgrave Macmillan. 